\title{
IMPLEMENTATION OF THE ADMINISTRATIVE-TERRITORIAL REFORM FOR A SUSTAINABLE DEVELOPMENT OF THE ECONOMY IN ALBANIA
}

\author{
Aurora Ndreu' \\ Karl-Franzens University of Graz, Graz, Austria
}

\section{ABSTRACT}

One of the main requirements of the European Union for countries that want to integrate this supra-national body, is the creation of large administrative units, in order to absorb easily and efficiently the funds obtained from pre-accession scheme. Through this reform it is meant to be achieved a good management of allocated funds regarding the socioeconomic development of the countries.

Given that the old territorial-administrative system that existed until 2014 when was adopted the new reform, had created imbalance between the development of regions and local units, unnecessary high costs merely used for operative expenses and staff salaries, not functioning properly of the local units and above all lack of public services delivery to citizens. As a result it was necessary to undertake a new reform where would be offered a new model of efficient organization.

The goal of reform should be the creation of local communities with a strong autonomy, capable of having the necessary capabilities and tools to encourage local development in all its aspects. In connection with the need for undertaking such a reform and its impact on the economy was agreed between political parties and throughout civil society. Problems and disputes between the parties began regarding the modus operandi of the drafting and implementation of the reform. In this paper I will show how the new territorial-administrative reform was drafted and adapted. The problems behind the theoretical drafting and putting it in practice. The impact in the development of the economy.

\section{UDC \& KEYWORDS}

UDC: 342'35 TERRITORIAL-ADMINISTRATIVE REFORM ECONOMIC DEVELOPMENT ALBANIA EUROPEAN UNION INTEGRATION DECENTRALIZATION

\section{INTRODUCTION}

Reforms undertaken at different times and different places are usually made to improve the existing situation in a particular area. Even the administrative and territorial reforms were developed with a specific target to improve the condition of the administrative and territorial organization. Usually these are carried out when the previous arrangements are not providing services optimally and have not been effective in meeting the final goal. (Hicks \& Kaminski, 1995) The goal of reform should be the creation of local communities with a strong autonomy, able to have the necessary capabilities and tools to encourage local development in all its aspects. As required the undertaken reforms must meet the following criteria. First, when required to make a reform, there must be the political will, without which reform can not be fulfilled. By legislative way it needs to have constitutional changes that would define the basic territorial division of a country, which would necessarily lead to the need of having the 'n.aurora@yahoo.com political will to be translated into votes during voting process in the parliament. After changing the constitution should be amended other laws on public administration, local government and its organization, or local finances. Changes in the law must be made on the basis of a complex analytical process and apply to all aspects that require changes. Then should be regulated by law all services provided to the public and the way how this should be done. In order a reform to achieve all the intended objectives, each service provided to the public should have a special arrangement by the law. Such an arrangement should be the adaptation of the law on local government finance. This is done not only by the law on the state budget, but also from other normative acts which are compiled on local budgets. In this regard, we should note that fiscal decentralization should go in proportion to the process of decentralization of public services. Local taxation laws should be tailored to reflect the reform and its changes. During the modification process should be take into account the process of harmonization with EU legislation. The experience of countries such as Poland in the implementation of reform gives us four important steps that must be taken into account when designing and implementing a reform (Yoder, 2003).

Firstly, the existence of a political consensus on the need for reform, the objectives and how reforms should be made.

Secondly, you need a strong support by international institutions, especially the European Union who works in similar subject matters. Their recommendations can be quite important as well as technical assistance itself.

Thirdly, technical discussions at the expert level and discussions with the political class and civil society on the delimitation of powers or criteria for delimitim territory.

Finally, the implementation of the reform requires a strong education of local leaders on how to implement the functionality making close visits in other countries where such reforms are implemented successfully.

Administrative-territorial reform is even more crucial in Albania, when the first problem it gets the fiscal problems and the efficiency and decentralization of public services. The division that exists in about 370 local units, not even meet efficiency criteria nor encourage a relationship between optimal fix sub-divisions of local and central government. Moreover, it was already an ongoing demand of the European Union to create the biggest administrative units or development regions in order to be responsible for the management of pre accession funds on economic and social development of candidate countries. (Ghinea \& Moraru, 2006) Previous reform of year 2000, in terms of regional development efficiency left much to be improved. This is proved by the fact that in many cases regional development policies have failed over the years, and from the fact that it was not achieved to reduce or disappear disparity in regional development imbalances between 
regions. Reasons for these failures were on the one hand the lack of power, which means the power to be limited and local institutions weak, and on the other the fact that there was not done a genuine study on how to create and delimitation of the regions generated in 2000. (Law on territorial-administrative reform, 2000) As mentioned, the division was done on the foundations of those existing local bodies and institutions, having already adapted some items, like the transition from rreth to qark ${ }^{1}$, as the term region is widely used in the literature and practice of European states. Consequently, counties or regions (qark) were created without a common interest or such profile and that did not help in their development. (Law on local government, 2000) The process of implementing reform, even as we shall see below, should include consultation on two very important elements. The decision on the reform should be the result of a consensus reached among the political class, determining the need for reform and the main directions of it, but on the other hand must be the result of broad consultation with civil society and interest groups affected directly from this reform. In addition it is necessary a preliminary study of all the different documents, studies, expertise in the relevant field, in order to find the best possible variables and more appropriate alternatives for the Albanian reality.

\section{The need for a territorial-administrative reform}

There are many reasons why a lot of determination was required to make the territorial reform in Albania. A reform that should be effective not only for the Albanian reality, but also to withstand time. As regard this reform should have been well studied and well approached with European Union legislation, because we aspire to EU membership in the short term. One of the main reasons for reform was the large financial costs of holding a large number of personnel in the local unit which didn't generate revenue and did not play on either their essential function to the provision of services to citizens as a result of mass movement from remote areas of rural to urban economies. In most local government units the number of the personnel and their administrative costs do not justify their existence. The state budget had over costs for wages and social security of the personnel of these units. This was due to the fact of low incomes and lack of funds to invest. On the other hand for a small country such as Albania, with a small population, and in the view of the first European reforms, it seemed excessive the presence of a big number of local units. In the European continent we see cases where there are countries with a population and area several times greater than Albania, but with a certain number of times smaller local units (Minister, 2015).

Thus, not only to adapt the reforms and co-exist with other countries of the EU, as a result of the integration process, but above all to cut all those unnecessary administrative costs and create further investment funds, the Albanian state assisted by foreign experts took the initiative to perform the administrative-territorial reform, such reform that was rumored long ago but never implemented. The reform would have an impact on domestic legislation, as it will bring much change on legislation, but more importantly can bring the change of the country's fundamental law, the Constitution. To prepare and change several laws and bylaws, or if necessary the constitution, requires not only expertise to be very good, but on the other hand a plurality of votes, expressed in number of votes in parliament. Such a reform, big and deep, which would bring drastic changes in the territorial-administrative organization would require time, which the government did not have enough. This because ${ }^{1}$ Local administrative unit in Albania

they wanted that local government elections of June 2015 to be developed on the basis of the new territorial organization. All this brought fear of a flawed process, that trying to rush to implement the reform within their deadlines, would make a reform truncated, expedited, half-reform, without preparing a good legislation, and above all without open public consultations, as provided for in the Constitution. In fact there were public meetings, but the meetings included a limited number of people, limited in the political party participation, within the political force that was due to implement the reform. All this rush to make the reform, made there was no consensus among the opposition nor wide consultations with the people. I think these two elements of great importance for such reforms with such an impact on the lives of citizens has to be implemented. As a result of this partial reform, today we have a reduced number of local units but have a legal vacuum which is very risky for local government. Currently we have new municipalities that operate with the old administration and the old legislation, unless the law 139/2015 on local selfgovernment was approved. (Local self-government Law, 2015) As for the mode of operation of the new local units, the large municipalities, for the moment we are in a administratively transitional phase, which is expected to be regulate on the basis of new legislation, laws, decisions of the council ministers or guidance that will emerge during 2016.

\section{Analysis of the existing situation of the local} government units

The last territorial-administrative division that was made was that made by law 8653 (Law on Territorial-administrative Reform, 2000) on the administrative and territorial units of local government in the Republic of Albania, where the country was divided into 12 districts, 65 municipalities and 308 communes. This law of 2000 , except that removed the concept of rreth already outdated, introduced the concept of the qark as administrative division, the number of municipalities and communes were kept as in 1992, by a simple decision of Council of Ministers. These previous organizations and divisions as from the studies we have collected, were not based on an in-depth research and analysis of units and their ability to carry on themselves such functions or capabilities. This reform was based on a symmetrical decentralization of functions and powers which make no difference in the size of local government unit or their capacity to perform these functions. But what matters most in all this is the fact that during those proceedings, there was not done any general public consultation with the people, which is the main constitutional obligation.

Studies of numerous tests conducted by non-governmental organizations but also government agencies in connection with the local government, show an enormous fragmentation of the territory where a large number of local units corresponds to a small population and a low capacity of developing the businesses in these units. According to the report accompanying ${ }^{2}$ the draft law on administrative division, this fragmentation and existence of small units of local government have been the main reasons listed for the non eficency on performance of provision public services by the latter. This was the reason also why did not allow a full decentralization by the central government. On the other hand such a need for this reform has been widely accepted by all political forces that have come to power, as well as by the international community in all its recommendations.

2 The report made by the territorial-administrative reform experts 
IMPLEMENTATION OF THE ADMINISTRATIVE-TERRITORIAL REFORM FO The discussion so far as well as the hypothesis or the main thesis was how efficient was the local government to date and how to achieve the objectives of providing services to citizens through the new division, through better use of funds and from being closer to the citizen.

\section{The proposed division according to the newly reform}

After making the analyzes and studies needed for each district, the Commission for the implementation of the reform, reached a final result where 5 variants were proposed for territorial- administrative division, that with 30 , $39,47,57$ and 63 local units. In all these variants they met somewhere more or less the criteria approved by the commission. In some variants was met more the functional criteria and in some others the institutional criteria of economic development or functionality, or in some that of traditional historical connection ${ }^{3}$. Variants proposed by the Commission were faced and compared with proposals made by the independent non-governmental organizations, and in most of them they agree, where the variants with 39 or 47 units better met the criteria of functionality. Thus the Commission on 22 May 2014 adopted the 39/47 version, which underwent a public consultation for two months and finally the Commission on July 17, 2014 came with the option of 61 municipalities, variant for the sake of truth which was not proposed either. As similar variant to this was that with 63 units, but that was not what the former proposed it in the final version. This change as was said, was made for the sake of respecting the rights of minorities. Finally the Commission opinion was sent to the judgment of Council of Ministers on 17 July 2014, under Article 68, paragraph 2 of the Law no. 8652 (Law on Local Government, 2000). The Council of Ministers on July 22, 2014 spoke positively about this decision and passed it to parliament for its approval (Commission, 2015).

\section{The benefits of this newly reform}

By presenting the focal points of this new reform we can find differences with the old division that existed. One of the most obvious benefits is the reduction to a considerable extent on the number of local government units from a total of 374 units, including 65 municipalities and 309 communes, into only 61 municipalities.

A positive side of this, is reducing to a considerable extent the administrative and operative expenses. This is because functions such as mayors or vice mayors of municipalities and communes, presidents and secretaries of municipal councils and commune councils were abolished since these units would not exist, and therefore there will be less spending. Other employees at the executive level will continue to be, although in a reduced number of them, as at the new administrative units created will remain open offices that would provide services to citizens. However administrative functions as a lawyer or a surveyor or engineer will be centered, which means these will be employees of the newly created entity. This will lead to increasing administrative efficiency in almost every local unit, as there will no longer overlap but there will be only a staff of well-trained that will afford an increased workload level. Such services provided from the new administrative units are like that of the civil status, the distribution of economic aid, inspection, rehabilitation of the territory, which can not be provided centrally by the big municipality as for the large distance from it. Reducing administration in these units in the extent of $30-40 \%$, which means cost savings of more financial income to invest. Reducing the number of 3 The study done for the project-law on the new territorialadministrative reform, p. 53 personnel could be seen as a positive way since it brings rationalization of human resources, aiming at enhancing the quality of the latter and reduce financial costs. We can also mention as a positive side on increased efficiency in public service given the fact that the funds will be higher and there will not be more fragmentation of funds, as we have already mentioned above. I said earlier that this brings the possibility to plan larger projects as offered because of a larger territory.

We hope that the new division will reduce or eliminate the disparity between local units that existed until now as a result of the difference between rural and urban areas, bringing redistribution of funds, but this standpoint in my vision will again bring problems because inequality would exist for itself, from the fact that municipalities are unequal in their creation.

As a result of this reform is expected to modernize and reduce the cost of services for utility services like drinking water supply, maintenance of school buildings and roads or sewer cleaning service. The new division will also bring cost savings as the procurement centers are centered on new municipalities and would not have unaffordable costs for businesses. On the other hand the possibility to take advantage of the various funds from abroad will be greater. All this is expected to bring a positive financial impact.

\section{Conclusion}

The problem regarding the new division, in our opinion, is that a division of 61 municipalities (excluding the single case of recognition of the right of minorities coming from international best practices) is still high, as there are municipalities that do not justify their separate existence and I believe it will bring the same problems as existed before reform.

Looking for differences between the old and current division, they emerge from the analysis made in the paper. While the positive side of reform, at least in theory, seems to be the use more effectively the revenue, reducing financial costs due to the reduction in the mass of the number of personnel.

Another would be providing service in a more efficient way as a result of the concentration within a territory. Through the expected sustainable economic development in Albania, namely reform expectations are very high, however, how this will be fulfill it has to be seen next. We are currently in the process of organizing the transition from the old to the new units and the implementation of this reform takes time.

\section{REFERENCES}

Commission (2015). The special Commission of the territorial-administrative reform. Relation on the draft-law "On the territorialadministrative reform in the Republic of Albania", retrieved september 2015 from http://reformaterritoriale.al/images/presentations/RE LACION\%20PROJEKTLIGJ\%20NDARJA\%20ADMINISTRATIVO_ TERRITORIALE.pdf

Ghinea, A., Moraru, A., (2006). Aspects regarding decentralization process in Romania. The administrative-territorial reform. Institute for Public Policy, Bucharest, Retrieved March 10, 2016 from http://www.ase.md/files/catedre/mgs/Decentralization_Process.pdf

Hicks, J. \& Kaminski, B. (1995, November). Local government reform and transition from Communism: The case of Poland, Journal of Developing Societies.

Local government law (2000). The Parliament of Albania, Law no 8652/2000. Retrieved February 20, 2016 from http://80.78.70.231/ $\mathrm{pls} / \mathrm{kuv} / \mathrm{f}$ ?p=201:Ligj:8652:31.07.2000

Law on the territorial-administrative reform in the Republic of Albania (2000). The Parliament of Albania, Law no 8653/2000. Retrieved February 15, 2016 from http://80.78.70.231/pls/kuv/ $f ? p=201:$ Ligj:8653:31.07.2000 
Local self-government law (2015). The Parliament of Albania, Law no 139/2015. Retrieved February 20, 2016 from http://www.ceshtjetvendore.gov.al/files/userfiles/LIGJI 1392015 PER_VETEQEVERISJEN_VENDORE1.pdf

Minister (2015). Minister of State for local government. "The actual situation of the local units in Albania" retrieved september 2015 from http://reformaterritoriale.al/images/presentations/Analiza_e_situate s_se_qeverisjes_vendore

Yoder, J. (2003). Decentralisation and regionalization after communism: Administrative and territorial reform in Poland and Czech Republic, Europea-asia studies, vol 55, pp 263-286 